\title{
Practices in the Teaching of Listening in Grade 9 EFL Classrooms of Mote Secondary School
}

\author{
Geleta Dugassa $^{1}$, Eba Mijena ${ }^{2 \star}$ and Ashenafi Bekele ${ }^{2}$
}

${ }^{1}$ External and Public Relation Office, Wollega University, Post Box No: 395, Nekemte, Ethiopia

${ }^{2}$ Institute of Language Studies and Journalism, Wollega University, Post Box No: 395, Nekemte, Ethiopia

\begin{abstract}
This study was designed to examine the practices in the teaching of listening in Grade $9 \mathrm{EFL}$ classrooms of Mote Secondary School. The study employed a descriptive survey design to attain the objective. The research used 108 Grade 9 students and 6 English language teachers who were teaching English as subjects of the study. To gather proper data for the study, questionnaire (both for students and teachers) and classroom observations were used. The data collected through questionnaire and classroom observations were analyzed both quantitatively and qualitatively. The findings of the study indicated that the teaching of listening in EFL classrooms (and that of English language teaching in general) is at a critical risk since teachers do not use the pre-listening, the while-listening and the post-listening activities to promote and facilitate the development of listening comprehension and because they never adapt or adopt activities which help students learn the skill effectively. Hence, the study recommended that an intensive training on classroom teaching and on the teaching materials which are currently in use are required for EFL teachers.
\end{abstract}

Copyright@2014 STAR Journal. All Rights Reserved.

Article Information

Article History:

Received : 08-10-2014

Revised : 17-12-2014

Accepted : 23-12-2014

Keywords:

Practice

Critical risk

Intensive training

Classroom teaching

Teaching materials

*Corresponding Author:

Eba Mijena

E-mail:

eba.mijena@gmail.com

\section{INTRODUCTION}

As a means of communication, listening plays an important role in people's lives. It is an active process where the listeners must engage fully in the day-to-day activities which demand them listen and comprehend. Besides this of course there are conditions where listeners listen only to speeches in their day-to-day lives and are not required to make any sort of interpretation. From these facts, one can see that listening can be of reciprocal or interactive and non-reciprocal or noninteractive. That means there are occasions where the listener is required to play an active role whereas there are conditions where the listener listens passively to a monologue or speech. Nevertheless, in the case of listening which takes place in EFL classroom contexts, it is mandatory to actively engage in the activity. To this end, various strategies must be used to promote the teaching of listening in EFL classrooms. For example, as suggested by Harmer (1991) and Brown (2006), listening for main ideas, listening for details, and listening and making inferences are some among the strategies. They indicate that these strategies, if they are used properly in the three phases of listening, help students understand the purpose for which they listen and the particular way of listening to be used. Hence, language teachers need to teach accordingly so as to promote the learning of listening skills.

Why the three phase of listening in EFL classrooms? Brown (2006), Vandergrif (1999) and Harmer (1991) emphasize that the proper implementation and use of the three phases of listening in their order consistently in the teaching of listening lead to the development of listening comprehension. As indicated in the aforementioned paragraph, one of the reasons is that this helps students properly comprehend the text. In the pre-listening phase, the teacher has to relate the text with students' background information. This is the stage where the teacher arouses the interest of his/her students in the listening and makes them feel at ease about the text they are going to listen to. It is also believed that some key vocabularies and sentence structures need to be introduced to students at this stage. The teacher has to make the purpose of listening clear to the learners as well. It is therefore the exposition of students to these activities at the pre-listening phase which facilitates students' listening comprehension. The while-listening phase is the phase where the students actually listen. The listening shall be made for different purposes: listen and draw, listen and choose, listen and fill-in the blanks, listen and complete, listen and rank, etc. This includes: listening for specific information and listening for main ideas where the learners are required to listen to the text to identify meanings like the implied meaning, where listening between the lines is needed. The post-listening stage is the stage where the students are encouraged to think beyond the text and relate the text with their own personal lives as well as through writing summery or other activities.

The bottom-up and top-down approaches are used to describe the different processes of listening (Wang Qiang, 
Geleta Dugassa, Eba Mijena and Ashenafi Bekele

2006). Robin and Guo Naizhao (2006) and Hedge (2002) indicate that, in the bottom-up model, listening comprehension is believed to start with identifying specific information, where the top-down strategies are used to identify the message in the language. Wang Qiang (2006) points out that listening for gist and making use of the contextual clues and background knowledge to construct meaning are emphasized in the top-down model. Writers such as, Robin and Guo Naizhao (2006) indicate that topdown strategies (like listening for the main idea, predicting, drawing inferences, and summarizing) are listener based; the listener taps into background knowledge of the topic, the situation or context, the type of text and language. This background knowledge activates a set of expectations that help the listener to interpret what is heard and anticipate what will come next.

The issues discussed in the previous paragraphs show that the use of different strategies and approaches by EFL teachers facilitate and promote students' listening comprehension. Nevertheless, there are lots of complaints from education stakeholders that such strategies and approaches are not properly used. It is clear that the practices in the teaching of listening determine the effective learning of listening skill. Therefore, this study was designed to investigate the practices in the teaching of listening in the Grade 9 EFL classrooms, focusing on the following basic questions:

1. To what extent do teachers use the phases of listening to facilitate the development of listening comprehension?

2. What are the challenges observed in the teaching and learning practices of listening in the Grade $9 \mathrm{EFL}$ classrooms?

\section{MATERIALS AND METHODS}

\section{Study Site and Research Design}

The study was conducted in Mote Secondary School Grade 9 EFL classes, Mote, East Wollega, Ethiopia. It employed a descriptive survey design.

\section{Respondents}

The respondents of the study were Grade 9 students and their English language teachers. The students' population was purposively selected so as to include students of different academic performance. There were 10 sections of Grade 9 with the total number of 682 students. There were 68 students in the 9 sections except one section which had 70 students. From the 9 sections, 10 students each were selected and 12 students were selected from the section which had 70 students. Accordingly, $15 \%$ (102) of the students were used as the sample of study. In support of this, Mertiler (2005) states that the sample between $10 \%-20 \%$ of the total population is recommended for descriptive studies. When it comes to the number of teachers, all the 6 English language teachers (i.e. 2 females and 4 males) were taken using the availability sampling technique. The teachers involved in the study had an experience of 4-10 years and had had a qualification of first degree in English Language Teaching. Of these, 3 teachers were selected by their consent for the classroom observation.

\section{Instruments}

Two instruments namely, questionnaire and observation were used to collect data for the study. To
Sci. Technol. Arts Res. J., Oct-Dec 2014, 3(4): 193-200

collect data about the practices in the teaching of listening, a questionnaire which consists of 21 close ended items was designed for the teachers. The first three items asked teacher's personal information. The next five dealt with the general information about the listening activities in the textbook. The last item consisted of 13 items which were designed to examine the extent to which teachers use the pre-listening, the while-listening and the post-listening activities in enhancing students' listening comprehension skills. The questionnaire was set in five point Lickert Scale (very high, high, medium, low and very low) which was adapted from the NCLRC (2004) and Lingzhu (2008).

Like that of teachers' questionnaire a questionnaire for students was designed to survey the classroom practices of the teachers while presenting or teaching of the listening skill to check whether the pre-listening, the whilelistening and the post-listening activities were presented in line with the three phases of listening or not. The items in the questionnaire were first prepared in English based on the literature. Then, they were translated into Afan Oromo (the local language) so that students could not misinform the researchers due to language barrier. It was aimed to examine whether their English language teacher help them identify and perform the activities needed to be performed at each stage of listening or not. Generally, 18 questions having two parts were designed. The first part asked students background information, the second part of the first seven focused on how often do their teachers presented the pre-listening activities at the pre-listening stage; the next three focused on how often their teachers presented the while-listening activities, and the last five focused on how often their teachers presented the postlistening activities. The questionnaire was set in five points Lickert Scale (always, usually, often, sometimes and never) and adapted from Rees (2008) and Lingzhu (2008).

Observation was employed to compare and validate the data obtained using questionnaire. In order to conduct classroom observation, two checklists were prepared. The first checklist had 15 items which had 14 sub-skills of listening were adapted from Richards (1985) and Rost (1990). Then, 3 volunteer teachers were observed four times each. The classroom observation was made for a month. After the observation sessions were completed, they were summarized and converted to 'Observed'/ 'Not observed' category. Some important notes were taken down from the 14 sub-skills of listening.

\section{RESULTS AND DISCUSSION}

\section{Results of Teachers' Questionnaire}

Teachers were asked how and what they think about the use of pre-listening activities in the EFL classrooms.

Table 1 depicts that the pre-listening activities activate the prior knowledge. Teachers were asked whether the purposes of the pre-listening, the while-listening and the post-listening stages are clearly stated in the teaching of listening. All of the respondents claimed that the purposes of each stage are not clearly indicated or stated in the listening sections so as to let learners identify the purposes of each stage. 
Table 1: Teachers' responses about the use of pre- listening activities

\begin{tabular}{|c|c|c|c|c|}
\hline No & Items & Responses & Frequency & $\%$ \\
\hline \multirow{3}{*}{1} & \multirow{3}{*}{$\begin{array}{l}\text { Do the pre-listening activities help students to activate } \\
\text { their prior knowledge about the topic? }\end{array}$} & Yes & 6 & 100 \\
\hline & & No & - & 0 \\
\hline & & Total & 6 & 100 \\
\hline \multirow{3}{*}{2} & \multirow{3}{*}{$\begin{array}{l}\text { Do the activities have variety to promote the learning of } \\
\text { listening? }\end{array}$} & Yes & 6 & 100 \\
\hline & & No & - & 0 \\
\hline & & Total & 6 & 100 \\
\hline \multirow{3}{*}{3} & \multirow{3}{*}{$\begin{array}{l}\text { Do the purposes of the pre-, the while- and the post- } \\
\text { listening stages used in the listening sections? }\end{array}$} & Yes & - & 0 \\
\hline & & No & 6 & 100 \\
\hline & & Total & 6 & 100 \\
\hline
\end{tabular}

\section{The Significance of Pre-Listening Activities}

Teachers were asked the significance of the prelistening activities.

Table 2 above shows teachers have different thinking on the extent to which pre-listening activities activate prior-knowledge. It can be seen that $33.34 \%$ (2) and $66.66 \%$ (4) of the teachers rated that the pre-listening activities as very high in activating students' prior knowledge and low in doing so, respectively. All teachers rated that the listening texts as low in letting students look at pictures and maps. Regarding Item 3, 33.34\% (2) of the teachers reported that as the pre-listening activities in the listening sections as very high in letting students predict what the text talk about while $66.66 \%$ (4) of the respondents replied as so do low in letting them. In Item $4,33.34 \%$ (2) of the teachers rated that the pre-listening activities in the listening text as high in letting teachers give clear instruction on how to perform the activity. The table also shows that $33.34 \%$ (2) of the respondents claimed that the pre-listening activities as low in letting teachers give clear instruction at the pre-listening stage. The other respondents replied that the pre-listening activities in the listening sections as very high or medium in letting teachers to give clear instruction. Regarding Item 5 , $(100 \%) 6$ of the respondents replied that as the prelistening activities in the listening text let teachers doing guideline practices. The last item of the pre-listening activities (Item 6) asked teachers whether the prelistening activities let them teach key words in context or not. $33.34 \%$ of the teachers rated that the pre-listening activities in the listening text as very high in letting teachers teach key words in context; on the contrary, $66.66 \%(6)$ of the teachers replied that the pre-listening activities in the listening text never let them teach key words in context.

Table 2: pre-listening activities in activating student's schemata

\begin{tabular}{|c|c|c|c|c|c|c|c|c|c|c|c|c|c|}
\hline \multirow{3}{*}{ No } & \multirow{3}{*}{$\begin{array}{c}\text { The pre-listening, the while- } \\
\text { listening and the post listening } \\
\text { activities } \\
\text { Pre-listening activities }\end{array}$} & \multicolumn{12}{|c|}{ Scale } \\
\hline & & \multicolumn{2}{|c|}{ Very high } & \multicolumn{2}{|c|}{ High } & \multicolumn{2}{|c|}{ Medium } & \multicolumn{2}{|l|}{ Low } & \multicolumn{2}{|c|}{ Very low } & \multicolumn{2}{|c|}{ Total } \\
\hline & & NO & $\%$ & NO & $\%$ & NO & $\%$ & NO & $\%$ & NO & $\%$ & No & $\%$ \\
\hline 1 & Activate students' prior knowledge & 2 & 33.34 & - & 0 & - & 0 & 4 & 66.66 & - & 0 & 6 & 100 \\
\hline 2 & $\begin{array}{l}\text { Make them look at pictures, maps, } \\
\text { and diagrams and guess what the } \\
\text { picture will be about }\end{array}$ & - & 0 & - & 0 & - & 0 & 6 & 100 & - & 0 & 6 & 100 \\
\hline 3 & $\begin{array}{l}\text { Let students predict what will come } \\
\text { in the next }\end{array}$ & 2 & 33.34 & - & 0 & - & 0 & 4 & 66.66 & - & 0 & 6 & 100 \\
\hline 4 & $\begin{array}{l}\text { Give clear instruction for the } \\
\text { activity }\end{array}$ & 1 & 16.66 & 2 & 33.34 & 1 & 16.66 & 2 & 33.34 & - & 0 & 6 & 100 \\
\hline 5 & $\begin{array}{l}\text { Let teacher doing guideline } \\
\text { practices }\end{array}$ & 2 & 33.34 & 2 & 33.34 & 2 & 33.34 & - & 0 & - & 0 & 6 & 100 \\
\hline 6 & $\begin{array}{l}\text { Dictate a list of words or let } \\
\text { teachers teach key words in } \\
\text { context }\end{array}$ & 2 & 33.34 & - & 0 & - & 0 & - & 0 & 4 & 66.66 & 6 & 100 \\
\hline
\end{tabular}

\section{The Practices in the Use of the While-Listening and Post-Listening Activities}

Teachers were asked the extent to which the prelistening and the while-listening activities promote the use of different activities, which is summarized in the Table given below.

Teachers were asked whether the extent to which the while listening activities let students listen and fill graphs and charts or not (Item 7). $66.66 \%$ (4) of the teachers rated that the while listening activities in the listening text as medium or low in letting students listen and fill in graphs and charts while, $33.34 \%$ (2) of the teachers rated that the while-listening activities in the listening text as very high in letting students listen and fill in graphs and charts. As to item 8, teachers were asked whether the while-listening activities in the listening text let students listen for gist or not. Regarding this, $66.66 \%$ (4) of the respondents rated that as medium in letting students listen for gist. $16.66 \%$ (1) of the respondents rated that the while-listening activities are high in letting students listen for gist whereas the rest $16.66 \%$ (1) of the respondents rated as so do low. Like item $8,66.66 \%$ (6) and $33.34 \%$ (2) of the teachers rated while-listening activities in the listening lessons as high and low in letting students search for specific clues to meaning respectively item 9 . The last item of the while-listening activities, Item 10 asked teachers whether the while listening activities in 


\section{Geleta Dugassa, Eba Mijena and Ashenafi Bekele}

EFL classrooms let students listen and fill blank spaces with correct words or phrases from the listening text or not. $50 \%(3), 33.34 \%$ (2) and $16.66 \%$ (1) of the teachers rated that as medium, high and very high in letting students listen and fill the blank spaces, respectively.

The last part asked teachers the extent to which the post listening activities in Grade 9 EFL classrooms let learners perform different activities. Item 11 asked teachers whether the post-listening activities in the listening text let students discuss and reflect their answers or not. $50 \%$ (3) of the teachers reported that the post-listening activities as low in letting students discuss and reflect the answers and $16.66 \%$ (1) of the respondents rated that the post-listening activities as very high in letting students discuss and reflect the answers. Whereas, the rest $33.34 \%$ (2) of the respondents reported that as very low in letting students discuss and reflect their answers. It might be for this reason that, $23.51 \%$ of the students who were asked on the same item replied that as their teachers never let them discuss and reflect the answers. Similarly, classroom observation, witnessed the same result, that is $66.66 \%$ (4) of the observed teachers were not noticed letting students discuss and reflect the answers.

Item 12 indicates that $33.34 \%$ (2) of the respondents rated that the post-listening activities as very high in letting teachers provide a related activity whereas $33.34 \%$ (2) of the teachers rated that the post-listening activities
Sci. Technol. Arts Res. J., Oct-Dec 2014, 3(4): 193-200

as low in letting teachers provide a related activity. And, the rest $33.34 \%(2)$ of the respondents rated that the postlistening activities as very low in letting teachers provide a related activity. Perhaps, it might be for this case that $54.91 \%$ of the students responded that their teachers never provided a related activity at the post listening stage. In the same way, in the classroom observation, of the three observed teachers, only one teacher was seen providing a related activity in 3 of the 12 observations. Thus, it can be inferred that the post-listening activities were not properly used in the ways that students learn listening skill properly. The last item asked teachers whether the post-listening activities let teachers give feedback or not (Item13). 16.66\% (1) of the respondents rated that the post-listening activities as very high in letting teachers give feedback. $50 \%$ (3) of the respondents rated that they so do high whereas $33.34 \%$ (2) of the respondents rated that the post listening activities as low in letting teachers give feedback. On the other hand, $66.66 \%$ (4) of the observed teachers were not noticed giving feedback for the students at post listening stage.

Generally, it was observed that teachers were not using the post-listening activities to promote the learning of listening in the ways that students recognize the post listening stage and identify the activities that should be performed at this stage.

Table 3: Teachers' responses to how far effectiveness of the while-listening and post-listening activities

\begin{tabular}{|c|c|c|c|c|c|c|c|c|c|c|c|c|c|}
\hline \multirow[b]{2}{*}{ II } & \multirow[b]{2}{*}{ While listening activities } & \multicolumn{2}{|c|}{ Very high } & \multicolumn{2}{|c|}{ High } & \multicolumn{2}{|c|}{ Medium } & \multicolumn{2}{|c|}{ Low } & \multicolumn{2}{|c|}{ Very low } & \multirow{2}{*}{\multicolumn{2}{|c|}{ NO Total }} \\
\hline & & NO & $\%$ & NO & $\%$ & NO & $\%$ & NO & $\%$ & NO & $\%$ & & \\
\hline 7 & $\begin{array}{l}\text { Let students listen and Fill in graphs } \\
\text { and charts }\end{array}$ & 2 & 33.34 & - & 0 & 2 & 33.34 & 2 & 33.34 & - & 0 & 6 & 100 \\
\hline 8 & Let students listen for gist & - & 0 & 1 & 16.66 & 4 & 66.66 & 1 & 16.66 & - & 0 & 6 & 100 \\
\hline 9 & Searching for specific clues to meaning & - & 0 & 4 & 66.66 & - & 0 & 2 & 33.34 & - & 0 & 6 & 100 \\
\hline 10 & Listen and fill the gaps & 1 & 16.66 & 2 & 33.34 & 3 & 50 & - & 0 & - & 0 & 6 & 100 \\
\hline III & Post-listening activities & & & & & & & & & & & & \\
\hline 11 & $\begin{array}{l}\text { Let students discuss and reflect their } \\
\text { answers/relate to their own experience }\end{array}$ & 1 & 16.66 & - & 0 & - & 0 & 3 & 50 & 2 & 33.34 & 6 & 100 \\
\hline 12 & $\begin{array}{l}\text { Invite teacher to provide a related } \\
\text { activity }\end{array}$ & 2 & 33.34 & - & 0 & - & 0 & 2 & 33.34 & 2 & 33.34 & 6 & 100 \\
\hline 13 & Let teachers to give feedback & 1 & 16.66 & 3 & 50 & - & 0 & 2 & 33.34 & - & 0 & 6 & 100 \\
\hline
\end{tabular}

\section{Results of Students' Responses}

Students were asked how teachers present the listening activities in the classroom.

Regarding Item 1, 42 students (41.18\%) claimed that their teachers tell them the purposes of the pre-listening activities sometimes whereas $22.55 \%, 6.87 \%$ and $8.83 \%$ of the students reported that their teachers often, usually and always tell them the purposes of the pre-listening activities respectively. Contrary to what most students replied, $25.49 \%$ of the students reported that their teachers never tell them the purposes of the pre-listening activities. From the classroom observation, it was observed that most of the teachers were not telling the purposes of the pre-listening activities to the students and do the teaching without doing it so. This creates a big challenge on students learning the listening- students do not feel at ease unless they are clear with the purpose of the activities. Thus, engaging students to pre-listening activities to activate students' prior knowledge towards the topic was not applied. In Item 2, (18.64\%) of the students replied that their teachers introduce the listening lesson topics always or usually, $38.24 \%$ and $30.40 \%$ of the students replied that their teachers did it so often and sometimes respectively, but $12.75 \%$ of the students replied that their teachers never introduced the topic. The classroom observation also has shown that only one teacher was observed introducing the topic properly while all the observed teachers rushed directly to reading aloud the listening text to the class. Introducing the topic to the class, help students to properly think on the topic ahead of the listening time (while listening stage). However, most of the observed teachers forgot presenting this important part of pre-listening activity.

The response on Item 3 showed that $9.82 \%, 13.73 \%$ and $34.32 \%$ of the students replied that their teachers asked a few questions always or usually, often and sometimes respectively. To the contrary, $42.16 \%$ of the students replied that their teachers never asked a few questions before presenting the listening text. In line to this, the classroom observation confirmed that $66.66 \%(2$ teachers) were not observed asking a few questions related to the topic before students being engaged to the 


\section{Geleta Dugassa, Eba Mijena and Ashenafi Bekele}

while listening activities. For Item 4, 49 students (48.08\%) indicated that their teachers do not ask questions that might help them predict what they are going to listen. The data obtained from classroom observation confirmed that $66.66 \%$ ( 2 teachers out of 3 ) were not observed asking students to predict what the listening text was about. Regarding Item 5, 36 students $(35.30 \%)$ replied that their teachers never teach key words in context while the same number of students i.e., $35.30 \%$ of the students replied that their teachers sometimes present keywords in context. In the classroom observation, of the three observed teachers, only one teacher was observed teaching key words in context by writing those key words on the blackboard giving along with its meaning in the context of the listening text. Thus, the practice of teaching some key words in context at the pre-listening stage was not properly addressed or implemented.

As to Item 6, 54 (52.95\%) of the students indicated that their teachers never set activities and let them listen while they were learning listening. While, 3.82\%, 7.85\% and $35.30 \%$ of the students reported that their teachers always, usually and sometimes did it respectively. The classroom observation, in the same way, affirmed what $52.95 \%$ of students responded, which displayed $66.66 \%$ ( 2 teachers) never set activities and let students listen the text. This means, out of 3 teachers, 2 teachers were not observed setting activities and letting them listen the text of the pre-listening activities in 12 observations carried
Sci. Technol. Arts Res. J., Oct-Dec 2014, 3(4): 193-200

out. They simply skipped setting the activities and letting them read the set activities rather they rushed directly to reading the text aloud. Contrary to this, 1 teacher was observed adapting the given text to the students' context and often set the activities and let students listen the text. The data, therefore, showed that of the observed, most teachers never set activities and let students listen the text. Like Item 6, 55 (53.93\%) of the students for Item 7 indicated that their teachers never gave them clear instruction on how to perform the activity. However, less than half of the students i.e., $7.95 \%, 6.87 \%$ and $31.38 \%$ claimed that their teachers gave them clear instruction on how to perform the activities always or usually, often and sometimes respectively. The classroom observation, also showed what most of the students replied, that is, of the 12 observations carried out, only one teacher was observed giving clear instruction on how to perform the activities in two observations carried out in his class. Giving clear instruction to the students at the pre-listening stage on how to perform the activities is advisable but teachers failed to do so.

Generally, from the analysis given above, it is possible to infer that teachers do not properly employ the prelistening activities or prospective tasks i.e., they do not practically manage the pre-listening activities. In addition, teachers were not in a position to inform their students on how to perform the pre-listening activities.

Table 4: Students' responses on how teachers' present the pre-listening activities

\begin{tabular}{|c|c|c|c|c|c|c|c|c|c|c|c|c|c|}
\hline \multirow{3}{*}{$\begin{array}{c}\text { No } \\
\text { I }\end{array}$} & \multirow{3}{*}{$\begin{array}{c}\begin{array}{c}\text { Teacher's Pre, While and post } \\
\text { listening activities }\end{array} \\
\text { Teacher's Pre-listening } \\
\text { activities }\end{array}$} & \multicolumn{12}{|c|}{ How often teachers practice in classroom teaching } \\
\hline & & \multicolumn{2}{|c|}{ Always } & \multicolumn{2}{|c|}{ Usually } & \multicolumn{2}{|c|}{ Often } & \multicolumn{2}{|c|}{ Sometimes } & \multicolumn{2}{|c|}{ never } & \multicolumn{2}{|c|}{ Total } \\
\hline & & No & $\%$ & No & $\%$ & No & $\%$ & No & $\%$ & No & $\%$ & No & $\%$ \\
\hline 1 & $\begin{array}{l}\text { Tells you the purposes of pre- } \\
\text { listening activities }\end{array}$ & 9 & 8.83 & 7 & 6.87 & 23 & 22.55 & 42 & 41.18 & 26 & 25.49 & 102 & 100 \\
\hline 2 & Introduce the topic & 7 & 6.87 & 12 & 11.77 & 39 & 38.24 & 31 & 30.40 & 13 & 12.75 & 102 & 100 \\
\hline 3 & $\begin{array}{l}\text { Ask a few questions related to the } \\
\text { topic }\end{array}$ & 3 & 2.95 & 7 & 6.87 & 14 & 13.73 & 35 & 32 & 43 & 42.16 & 102 & 100 \\
\hline 4 & $\begin{array}{l}\text { Ask students to predict what they } \\
\text { are going to listen }\end{array}$ & 1 & 0.98 & 1 & 0.98 & 14 & 13.73 & 37 & 36.28 & 49 & 48.03 & 102 & 100 \\
\hline 5 & Teach key words in context & - & 0 & 8 & 7.85 & 22 & 21.57 & 36 & 35.30 & 36 & 35.30 & 102 & 100 \\
\hline 6 & Setting tasks and letting them read & 2 & 1.96 & 2 & 1.96 & 8 & 7.85 & 36 & 35.30 & 54 & 52.95 & 102 & 100 \\
\hline 7 & $\begin{array}{l}\text { Give clear instruction on how to } \\
\text { perform the activity }\end{array}$ & 2 & 1.96 & 6 & 5.89 & 7 & 6.87 & 32 & 31.38 & 55 & 52.93 & 102 & 100 \\
\hline
\end{tabular}

Students' Response to their Teacher's Presentation of the while and Post-Listening Activities

This section presents the students' responses to their teachers' use of the while- and post-listening activities.
Items 8,9 and 10 focus on the while-listening activities and the rest (11-15) on the teachers' use of post-listening activities.

Table 5: Students' response to the how often do teachers presented the while and post-listening Activities

\begin{tabular}{|c|c|c|c|c|c|c|c|c|c|c|c|c|c|}
\hline \multirow{2}{*}{ II } & \multirow{2}{*}{ Teacher's While listening activities } & \multicolumn{2}{|c|}{ Always } & \multicolumn{2}{|c|}{ Usually } & \multicolumn{2}{|c|}{ Often } & \multicolumn{2}{|c|}{ Sometimes } & \multicolumn{2}{|c|}{ Never } & \multicolumn{2}{|c|}{ Total } \\
\hline & & No & $\%$ & No & $\%$ & No & $\%$ & No & $\%$ & No & $\%$ & No & $\%$ \\
\hline 8 & $\begin{array}{l}\text { Reading the text according to the } \\
\text { students level }\end{array}$ & 2 & 1.96 & 9 & 8.83 & 54 & 52.95 & 24 & 23.53 & 13 & 12.73 & 102 & 100 \\
\hline 9 & Observing and guiding students & 2 & 1.96 & 9 & 8.83 & 27 & 26.47 & 38 & 37.26 & 26 & 25.48 & 102 & 100 \\
\hline 10 & $\begin{array}{l}\text { Make students aware of that they can } \\
\text { interrupt and ask }\end{array}$ & 3 & 2.95 & 1 & 0.98 & 13 & 12.75 & 41 & 40.20 & 44 & 43.12 & 102 & 100 \\
\hline III & Teacher's post listening activity & & & & & & & & & & & & \\
\hline 11 & $\begin{array}{l}\text { Let students discuss and reflect their } \\
\text { answers }\end{array}$ & 4 & 3.93 & 8 & 7.85 & 15 & 14.71 & 51 & 50 & 24 & 23.51 & 102 & 100 \\
\hline 12 & Give feedback & 5 & 4.91 & 10 & 9.81 & 33 & 32.36 & 38 & 37.26 & 16 & 15.66 & 102 & 100 \\
\hline 13 & Provide a related task & 2 & 1.96 & 6 & 5.89 & 11 & 10.79 & 27 & 26.45 & 56 & 54.91 & 102 & 100 \\
\hline 14 & Check the students' work & 2 & 1.96 & 9 & 8.83 & 34 & 33.34 & 37 & 36.26 & 20 & 19.61 & 102 & 100 \\
\hline 15 & $\begin{array}{l}\text { Teach some language items in the } \\
\text { listening text }\end{array}$ & 1 & 0.98 & 5 & 4.91 & 12 & 11.77 & 34 & 33.34 & 50 & 49 & 102 & 100 \\
\hline
\end{tabular}




\section{Geleta Dugassa, Eba Mijena and Ashenafi Bekele}

Regarding item $8,23.53 \%, 52.95 \%$ and $10.79 \%$ of the students replied that their teachers did sometimes, often and always or usually respectively. The classroom observation also confirmed this i.e., the classroom observation revealed that the entire observed teachers always read the text aloud twice. However, this could be done by the teachers, but it was difficult for the students to comprehend the message. For Item 9, 38 students $(37.26 \%)$ replied that their teachers sometimes guide them at while-listening stage whereas $26.47 \%$ (27) of the students replied that their teachers often guide them at while-listening activities. However, $25.48 \%$ (26) of the students replied that their teachers never guide them at while-listening stage. The classroom observation also revealed that most of the observed teachers were not guiding students at while-listening stage i.e., in the 12 observations carried out, only one teacher was observed while he was guiding and observing students.

As to Item 10, $40.20 \%(41), 12.75 \%$ (13) and $3.93 \%$ (4) of the students respectively reported that their teachers sometimes, often and always or usually let students interrupt and ask questions. While, 43.14\% (44) of the students reported that their teachers never ask. The classroom observation totally supported what $43.14 \%$ (44) of the students replied, i.e., 3 of the observed teachers did not do it so. In another way, in the 12 observations carried out, no one was noticed making students aware of that they can interrupt and ask at the while-listening stage. Therefore, it is clear that teachers dominantly practice reading aloud the text, ignoring other online tasks or other while-listening activities. Most of the teachers focused only on practicing reading aloud the text. In fact, this can help students fill gap filling questions, T/F comprehension if questions were given at the pre-listening stage. Thus, it is possible, to conclude that, like the pre-listening, the while-listening activities or the on-line activities were not properly handled.

Students were asked how often their teachers let them discuss and reflect their answers (Item11). 50\% (51), $14.71 \%(15)$ and $11.78 \%(12)$ of the students replied that the teachers sometimes, often and always or usually did it respectively. $23.51 \%$ (24) of the students, on the contrary, replied that their teachers never let them discuss and reflect the answers. $66.66 \%$ of the observed teachers were not noticed letting students discuss and reflect their answers, whereas, (33.34\%) one teacher was seen letting students often discuss and reflect their answers. Letting students discuss and reflect the answers is one of the fundamental post-listening activities that can help learners to share their ideas, reflect their feelings, relate to their personal experiences and develop interactive listening. Teachers, however, neglected this important part of postlistening activity.

Students were asked, on Item 12, whether their teachers give them feed-back at the post-listening stage or not. $37.26 \%(38), 32.36 \%(33)$ and $14.72 \%(15)$ of the students replied that their teachers sometimes, often and always or usually give them feedback, respectively. While $15.69 \%$ of the students replied that their teachers never give them feed-back at the post-listening stage. Most of the students replied that their teachers did it sometimes, often and always or usually, but classroom observation revealed what $15.69 \%$ of the students replied refuting what most students claimed. That means, $66.66 \%$ (2) of the observed teachers were not observed giving feedback
Sci. Technol. Arts Res. J., Oct-Dec 2014, 3(4): 193-200

at the post-listening stage. In the 12 observations made, only one teacher was seen giving them feed-back in 3 of the 4 observations carried in his class. Concerning Item 13 , students were asked, whether their teachers provide a related activities at the post-listening stage or not. More than half $(54.91 \%)$ of the students reported that their teachers never provide a related activity that should be performed at the pos-listening stage. While, $26.45 \%$ (27), $10.79 \%(11)$ and $7.85 \%(8)$ of the students replied that their teachers sometimes, often and always or usually provide a related activity, respectively. The classroom observation showed what $54.91 \%$ (55) of the students replied. That means, of the 3 observed teachers, only teacher was noticed providing a related task in 2 observations.

As to Item 14, 36.26\% (37), 33.34\% (34) and 10.79\% (11) of the students replied that their teachers sometimes, often and always or usually checked the students work, respectively. While, $19.61 \%(20)$ of the students witnessed that their teachers never checked their students' work at post-listening stage. The classroom observation, in contrary to the majority of the students' response, but, supported what the minority of the students replied. That means, only one teacher (33.34\%) one teacher was observed sometimes checking students' work whereas $(66.66 \%) 2$ teachers were not observed checking students' work. The last Item concerned with teaching some language items in the listening text (item15). $33.34 \%(34), 11.77 \%$ (12) and $5.89 \%$ (6) of the students reported that their teachers sometimes, often and always or usually taught some language items in the listening text, whereas, almost half $49 \%$ (50) of the students replied that their teachers never taught some language items in the listening text at post-listening stage. The classroom observation also revealed that the entire teachers were not observed teaching some language items.

In sum, depending on the analysis made above, it can be inferred that what most students claimed about the how often their English language teachers presented the pre, while, and post-listening activities was practically observed in the classroom. That is to say, the majority of the pre, while and post-listening activities were not properly practiced. This might have been because of the following reasons:

a) of the four skills, listening was not emphasized by teachers thought that no room was given to assess this skill, that means, no room was given to test this skill using tests, final and national examinations.

b) Teachers were not in a position to prepare supplementary activities and to adapt the listening text exist in the textbook when needed and they have forgotten as they are the concerned body to do.

c) The pre- and the post-listening activities of the listening text are not consistently designed.

\section{Analysis of the Classroom Observation}

An observation checklist was used to see the extent to which teachers presented the pre-listening, whilelistening and post-listening activities in the ways that develop/promote students' listening comprehension skills and develop these sub-skills or not.

Regarding telling the purposes of pre-listening activities to the students, the actual classroom observation revealed that only one teacher was observed telling the purposes of pre-listening activities in 2 of the four observations carried out in his classroom. While, the 


\section{Geleta Dugassa, Eba Mijena and Ashenafi Bekele}

rest two were not observed telling the purposes of the prelistening activities in the 8 observations carried out in their classroom. The second pre-listening activity observed at actual classroom observation was introducing the day's lesson carefully. Teacher 1 and Teacher 2 were observed introducing the day's lesson in observations $\mathrm{O} 3$ and $\mathrm{O} 2$ respectively. Both of them rushed to reading the listening text aloud by saying 'listen and answer the questions' skipping introducing the day's lesson. Teacher 3 was observed introducing the day's lesson clearly in observations $\mathrm{O} 2, \mathrm{O} 3$ and $\mathrm{O} 4$. In case of Teacher 3, at $\mathrm{O} 1$ the actual while-listening phase and introducing the day's lesson was not separately presented.

Other pre-listening activities observed using a checklist were: asking a few questions related to the topic, ask students to predict what they are going to listen and ask students to predict what they are going to listen. Teacher 1 and Teacher 2 were not observed letting the students to perform the activities whereas T3 was observed letting students to perform or do all of the activities. Regarding teaching key words in context, of the three observed teachers, only Teacher 3 was observed teaching key words in context by writing those key words on the blackboard and giving its meaning in the context of the listening text in all of the four observations carried out for his class. T1 and T2 were not observed teaching key words in context in observations $\mathrm{O} 1, \mathrm{O} 2, \mathrm{O} 3$, and $\mathrm{O} 4$ carried out for both on the four lessons. Thus, the practice of teaching some key words in context at the pre-listening stage was not properly addressed or implemented. Setting activities and letting students read the activities were also observed to check whether teachers set activities and let students read before the actual listening phase. Of the three observed teachers, Teacher 3 was observed setting activities and letting students read before the while- listening stage in order to aware the learners, in all the observations carried out that is in observations 01 , $\mathrm{O} 2, \mathrm{O} 3$, and O4. Contrary to this, Teacher 1 and Teacher 2 were not observed setting activities at pre-listening stage in all of the observation carried out.

Observation was made regarding giving clear instruction for the students on how to perform the activity using a checklist. Regarding this, Teacher 1and Teacher 2 were not observed giving clear instruction on how to perform the activities of each stage in all of the observations carried out. The result of the classroom observation revealed that two of the observed teachers did not apply the pre-listening activities in general. For example, telling the purposes of pre-listening activities, introducing the day's lesson, teaching key words in context and giving clear instruction at pre-listening stage, instead of doing this, they rushed directly to reading the listening text without activating students' prior knowledge towards the topic. Whereas, one teacher tried his best to let learners familiarize with the pre-listening activities, letting students to perform the pre-listening activities used in the checklist as intended. Generally, from the observed actual classroom activities of the pre-listening phase, it can be deduced that the observed teachers were not properly using the pre-listening activities or prospective tasks i.e., they did not practically employed the prelistening activities. In addition, teachers were not in a position to inform their students on how to perform the pre-listening activities.
Sci. Technol. Arts Res. J., Oct-Dec 2014, 3(4): 193-200

The actual classroom activities of the while-listening activities were also observed using a checklist to see whether teachers present in the way intended to be presented to promote students' listening comprehension skills. The first actual while-listening activity observed was reading the listening text according to the students' level. Regarding this, three of the observed teachers were observed reading the listening text aloud to the class in the 12 observations carried out. The second actual classroom activities of the while-listening activities observed was observing and guiding students. Concerning this, Teacher 1 and Teacher 2 were not observed observing and guiding students. However, Teacher 3 was observed observing and guiding students at while-listening stage. The last item of actual classroom activities of the while-listening activity observed was making students aware of they can interrupt and ask. Three of the observed teachers were not observed making students aware of that they can interrupt and ask questions in the 12 observations carried out.

The actual classroom activities of the post-listening stage, in the same way, observed using a checklist. The first actual classroom activity of the post-listening stage was letting students discuss and reflect the answers. Teacher 1 and Teacher 2 were not observed letting students discuss and reflect the answers at post-listening stage in observations $\mathrm{O} 1, \mathrm{O} 2, \mathrm{O} 3$, and $\mathrm{O} 4$. Contrary to this, Teacher 3 was observed letting students discuss and reflect the answers in four of the actual classroom observation held. Engaging students to discuss and reflect the answers help to share and reflect information, relate their experiences to the text, make analysis of the language forms, to integrate the lessons with the other skills. However, two of the observed teachers, neglected, this important activity of the post-listening stage.

The second actual classroom activity of the postlistening stage was giving feedback for the students on their work. In relation to this, Teacher 1and Teacher 2 were not observed giving feedback on the exercises or the activities set or provided at pre-listening stage on all of the observations carried out. Teacher 3 was seen giving feedback in 3 of the four observations carried out in his class. Providing a related activity is another post-listening activity that was observed in actual classroom activities of the post-listening stage. Teacher 1 and Teacher 2 were not observed providing a related activity in order to make learners relate to their real life situation and to what really exists. Teacher 3 was observed providing related activities in 3 of the 4 observation carried out in his class. In one of his classroom observation, he was not observed giving a related activity to let learners deal on. Checking the students' work and teaching some language items in the listening text is the last observation checklist used. Similar to that of providing a related activity, Teacher 1 and Teacher 2 were not observed checking their students work at post-listening stage in all of the observations carried out; whereas, Teacher 3 was observed checking his students work in $\mathrm{O} 2, \mathrm{O} 3$, and $\mathrm{O} 4$. Concerning teaching some language items in the listening text, three of the observed teachers, were not observed teaching some language items in the listening text in all of the observation carried out.

Generally, from the classroom observation carried out, one can infer that the pre-, the while-and post-listening activities of the pre-, the while and the post-listening 


\section{Geleta Dugassa, Eba Mijena and Ashenafi Bekele}

stages were not properly practiced by the teachers. Teachers are the concerned body to prepare supplementary materials and activities, and to adapt the listening text when needed but not realized by them.

\section{CONCLUSIONS}

The main objective of the study was to examine the practices in the teaching of listening to Mote Secondary School Grade 9 EFL students. To collect data for the study, questionnaire and classroom observation were used. Accordingly, the research has shown that the prelistening, while-listening and post-listening activities which are suggested by ELT scholars were not properly used by teachers in classroom teaching. The classroom observation also revealed the same result. For example, from the observed teachers $66.66 \%$ of the teachers were not observed employing the listening activities for each stage. From the pre-listening activities, introducing the day's lesson was employed by the teacher, but the rest pre-listening activities were not totally employed. In addition, teachers were not in a position to inform their students on how to perform the pre-listening activities. From the while-listening activities, it was observed that the teachers were reading the text aloud. The post-listening activities were not totally practiced. Teachers are the concerned body to prepare supplementary activities and to adapt the listening text when needed, but they didn't do so.

Based on the findings of the study, the following conclusions were drawn:

1. Students were not aware of the phases of listening and the activities to be performed at each stage of listening because their teachers do not inform them about the phases.

2. The majority of the teachers haven't been properly using the listening activities for each listening stage.

3. Teachers are the concerned body to prepare supplementary activities and to adapt listening text when needed as suggested by ELT scholars, but they didn't do so.

Based on the conclusions made above, the following recommendations have been forwarded.

- The theoretical part of teaching listening skill needs to be presented to the students from the very beginning.
Sci. Technol. Arts Res. J., Oct-Dec 2014, 3(4): 193-200

- Why teachers couldn't prepare supplementary activities and adapt listening text when needed as suggested by ELT Scholars need to be investigated.

- Appropriate training on how to teach listening skills and how to prepare and/or adapt the listening materials should be given for English language teachers.

\section{REFERENCES}

Brown, S. (2006). Teaching Listening. Cambridge: Cambridge University Press.

Harmer, J. (1991). The Practice of English Language Teaching. Longman.

Lingzhu, J. (2008) Lingzhu Listening Activities for Effective Top- processing. Retrieved on 7/31/2014 from http://itesli.org/Techniques/LingzhuListening.html

Ministry of Education. (2002 E.C.). English for Ethiopia Grade 9 Teacher's Guide. Addis Ababa: Ethiopia. Ministry of Education. (2003 E.C.). English for Ethiopia Grade 9 Student's Textbook. MOE: Mega Printing Press

National Capital Language Resource Center (2004).Teaching Listening: Developing Listening Activities. Retrieved on 8/26/2014 from http://www.nclre.org/essentials/listening/ develop/listen.htm

Rees, G. (2008). Pre-listening Activities. Retrieved on 25/3/2014 from http://www.teachingenglish.org.uk/think/ knowledge-wiki/pre-listening

Richards, J.C. (1985). The Context of Language Teaching. Cambridge: Cambridge University Press.

Rost, M. (1990). Listening in Language Learning. London: Longman.

Underwood, M. (1989). Teaching Listening. New York: Longman.

Vandergrift, L. (1999). Facilitating second language listening comprehension: Acquiring successful strategies. ELT Journal 53(3): 168-176.

Wang Qiang. (2006). A course in English Language Teaching. Beijing: Higher Education Press.

Wilson, M. (2003). Discovery listening - Improving perceptual processing. ELT Journal 57(4): 335-343. 